\title{
Confucianism's influence on ethics education in South Korea
}

\author{
Faruk Levent ${ }^{1}$ \\ Meral Pehlivan ${ }^{2}$
}

\begin{abstract}
One of the main functions of educational institutions is to cultivate individuals of good character. However, this situation necessitates systematic and effective ethics education. In this regard, teachers, the implementers of educational programmes, play a critical role in conveying ethical values to their students. In addition to its success in international student assessment examinations, South Korea is a Far East country distinguished for its continuous focus on the ethical values of individuals and the training of high-quality teachers. Therefore, the purpose of this study is to examine the influence of Confucianism on ethics education in South Korea. The implication of this study is that it contributes to the educational sciences literature on teacher training systems and ethics education in South Korea, a country of strong social structure in terms of the value given to education and commitment to Confucian teachings.
\end{abstract}

Keywords: Ethics education; Confucianism; South Korea.

\section{Introduction}

Confucius, who lived in China between 551-479 B.C., not only influenced the country and his time, but also had an impact on all East Asian countries for subsequent centuries (Chu \& Carew, 1992; Yum, 1994; Fitzgerald, 1994; Dirlik, 1995; Lu, Gilmour \& Kao, 2001; Chung, 2001; Shin \& Koh, 2005; Starr, 2012; Chou, Tu \& Huang, 2013; Park \& Müller, 2014). The influence of Confucian principles in South Korea is not only seen in culture and education (Canda, Shin \& Canda, 1993; Canda \& Canda, 1996; Lim \& Choi, 1996; Chen \& Chung, 1997; Lee, J-K., 2001), but also in ethics education (Moon, 1995; Baek, 2002; Jeong, 2005; Park \& Müller, 2014). Many Western authors (e.g. Hofstede, 1980; Psacharopoulos, 1984; Hofstede \& Bond, 1988; Hart, 1993; de Bary, 1996; Tu Wei-ming, 1996; quated in Lee, I-J., 2001) have mentioned the catalyst effect of Confucian principles on the economic development of South Korea and the modernisation of higher education in this Far East nation.

South Korean culture places high importance on interpersonal relationships, ethical values and social benefits, the latter of which precede the welfare (with respect to tradition and authority) of individuals (Lim ve Choi, 1996; Plantilla \& Raj, 1997; Choi ve Han, 2008). Naturally, such aspects are also visible in the Korean language. For instance, in the translation of Korean into English, the words we and our are used instead of $I$ and me. The Korean language also maintains the divergent levels when showing respect to others and acknowledging the hierarchical structure in society (Joh, 2002). Overall, Confucian principles have had a significant influence on this particular culture (Starr, 2012).

\footnotetext{
${ }^{1}$ Assist. Prof. Dr., Marmara University, Ataturk Faculty of Education, Istanbul, faruk.levent@marmara.edu.tr

2 Ph.D., Student, Marmara University, Institute of Educational Sciences, Istanbul, meralpehlivan@gmail.com
} 
Numerous researchers have examined the factors that have affected the success of South Korea's education, thus adding to the enlightening studies of different aspects (Levent \& Gökkaya, 2014). According to Arjoon (2001), although South Korea's success in education has generally been regarded as academic, the students' levels of self-discipline and national solidarity have greatly contributed to such success. Fangchuan (2010) suggested that these two characteristics are the impulsive forces behind Asian students' diligence in studying for long hours.

According to the common view acknowledged by scientists, education is comprised of three main components: teachers, students and curriculums (Kim, Chung \& Kim, 2012, p. 6). Many researchers have pointed out that teachers are the most important elements in increasing the quality of teaching (Kim \& Han, 2002; Kwon, 2004; Park, S., 2010). Aydin (2015) defined the profession of a teacher as 'the art of cultivating a generation as a good person and a good citizen for his/her family, environment, nation and country'. Based on this definition, it is the case of teaching ethical values to the students and preparing them for their social roles in the future as much as equipping them with knowledge and skills (Bakioglu \& Silay, 2014, p. 121). In other words, teachers play a crucial role in fostering individuals with ethical values and introducing them into society by means of education. Correspondingly, it is of utmost importance that the teachers, who, in some cases, affect the students more than their parents, are committed to universal ethical principles (Pieper, 2003, p. 145). In regard to South Korea's success, of which its education system is based on Confucian principles, ethical values play a significant role (Shin \& Koh, 2005). Therefore, the purpose of this study to examine the influence of Confucianism on ethics education in South Korea.

\section{Historical overview of education in South Korea}

In regard to the historical development of South Korea's education system, especially between 1953 and 1960, considerable changes in many areas of life occurred, along with the rapid economic development. As a result, the education system struggled to respond to such qualitative development. For example, in 1945, only $40 \%$ of school-aged children attained a sixth-grade education. However, 15 years later, this ratio increased to 96\% (Seth, 2005). Despite the economic problems and poverty issues, the South Korean people continued to invest in human capital (Lee, J., 2001). During these extensive efforts, their belief in educational development and its effect on economic growth was important (Jeong \& Armer, 1994; Green et al., 1999; quoted in Park, S.Y, 2010). After an act was legislated in 1953, the legal basis for establishing temporary educational institutes was laid. It was during this period that an effort to establish a teacher education system in the direction of the American system was apparent. In addition, in-service trainings were not only conducted for the teachers, but for the principals and vice-principals.

In the 1960s, due to the rapidly increasing student population, the inadequacy of quality teachers brought the shortage of educational opportunities and caused severe competition in the university entrance system. Such inadequacies required reforms of this system, which included normalising all school levels and creating a new university entrance system. One educational reform in particular, was the establishment of teacher training and in-service graduate schools (MOE, 2014a).

The modernisation of education to increase its quality continued with the government's successoriented educational policies in the 1980s. Unlike the earlier quantitative developments, the new policies focussed on quality development. Moreover, for the first time, the need for lifelong education was stated in the Constitution, of which the following aims were expressed (MOE, 2014a): 1) Implement the Social Education Act and the Early Education Promotion Act; 2) Abolish the main entrance examination and introduce a more high school achievement-focussed system; 3) Establish a broadcasting system of education service; and 4) Establish a quota system for college graduates. 
Levent, F. \& Pehlivan, M. (2017). Confucianism's influence on ethics education in South Korea. Journal of Human Sciences, 14(1), 321-330. doi:10.14687/jhs.v14i1.4372

In March 1985, the Education Reform Commission was inaugurated as a consultative body for the President. Overall, 10 innovative measures, referred to as Cultivating Koreans to Lead the 21st Century, were planned to be put into practise by December 1985. These measures included the following (MOE, 2014a):

- Improving the university entrance system via educational reforms

- Upgrading school facilities

- Securing high-quality teachers

- Fostering science education

- Improving higher education

- Encouraging autonomy in educational administration

- Establishing a lifelong education system

- Enlarging educational investments

The main goal of education in South Korea is to ensure that each citizen becomes a self-confident individual who can contribute to the democratic development and social welfare of the nation in particular and mankind in general (MOE, 2014b). Aligned with this goal, one of the aims of the 7th National Curriculum, which was implemented in 2000, was to bring an educated individual to the level that he/she can both 'create new values for the national culture' and 'contribute to the development of the community on the basis of democratic civil consciousness' (MOE, 2014a).

\section{Ethics education in South Korea}

In South Korea, Confucian teachings underlie the practical ethical behaviours guiding everyday life (Leong, Huang \& Mak, 2013). After all, the most important value that Confucius brought to basic education is that he introduced ethics education and emphasised the importance of providing education for all people without discrimination. In this educational context, the purpose was to help students develop an ideal personality (Chen \& Chung, 1997, p. 322). According to Starr (2012), Confucius pointed out the importance of possessing ethical values by stating the following: Needs and material gains are important. However, it is not right to gain at the cost of losing ethical values'.

South Korea is one of the rare countries that regularly provide ethics education in each year of its 12-year education system (Moon, 1995). More specifically, ethics is one of the 10 compulsory subjects in primary and secondary schools. In regard to the latter, they are categorised into general academic high schools and vocational high schools, and the ethics course is compulsory in both types of schools (International Qualifications Assessment Services, 2009).

Moon (1995) categorised the periods of change in the ethics curriculum of South Korea into six groups, as shown in Table 1.

Table 1: Periods of Change in the Ethics Curriculum

\begin{tabular}{|c|c|}
\hline $\begin{array}{l}\text { 1. Moral Education Curriculum } \\
22 \text { September } 1945\end{array}$ & $\begin{array}{l}\text { Developed under the U.S. military government's effect, it focussed on } \\
\text { civics. }\end{array}$ \\
\hline 2. Moral Education Curriculum & After the Korean War, it focussed on anti-communism and economic \\
\hline 20 April 1954 & rehabilitation; that is, it was about returning to traditional values. \\
\hline 3. Moral Education Curriculum & With the economic growth, it aimed to forward the virtues supporting \\
\hline 14 February 1973 & modernism and establish a Korean-style democracy. \\
\hline 4. Moral Education Curriculum & Under the effect of the cognitive-developmental approach, it focussed \\
\hline 31 December 1981 & $\begin{array}{l}\text { on the systematic teaching of virtues. This education began to involve } \\
\text { reasoning and discussions. }\end{array}$ \\
\hline $\begin{array}{l}\text { 5. Moral Education Curriculum } \\
30 \text { June } 1987\end{array}$ & $\begin{array}{l}\text { A holistic identity and defence-oriented moral education emerged from } \\
\text { the pluralistic way of life along with the anti-communist approach. }\end{array}$ \\
\hline $\begin{array}{l}\text { 6. Moral Education Curriculum } \\
30 \text { June } 1992\end{array}$ & $\begin{array}{l}\text { In addition to emphasising communitarian ethics, integrated moral } \\
\text { education of all school subjects was common. }\end{array}$ \\
\hline
\end{tabular}

Source: Adapted from Moon (1995). 
Soon after the moral education curriculums (Table 1) were described, the term, character education, was introduced into the Korean education system on 31 May 1995. In a report prepared by the Education Reform Commission, the importance of a strong moral character in students was emphasised, along with creativity. In addition, this committee pointed out that it was more important to develop one's character not only in a specific subject, but also in all subjects that convey information. The committee also drew attention to various problems, such as peer bullying, theft and lying, all of which stemmed from the lack of this educational motive. With this report, $A$ Practical Character Education Reinforcement Plan was implemented in schools throughout the country (Joh, 2002, p. 398).

In South Korea, based on its long history of cultural and spiritual wealth, it is believed that ethical values are informally conveyed at the extra-curricular level, in addition to formal education. During this process, a teacher's behavioural approach and his/her relationship with a student's family can improve the quality of education. Sorensen (1994) stated that the importance of this relationship is based on the common purpose between the teacher (the principal authority) and the student's family, rather than the continuous interactions between both parties. In other words, the word of a teacher is the law for the student's family.

The Korean Ministry of Education supervises the character education programme at schools and prepares the ethics education curriculum for information technology (IT) use. In addition, the Ministry encourages schools to realise experience-based character education for secondary students by discussing various case studies. Through such discussions that focus on civic education, the purpose is to teach students about personal responsibility and basic life habits (MOEHRD, 2004).

In order to teach students about ethical values, it is expected that the teachers also possess such values. In other words, the main responsibility in ethics education is placed on the teachers, rather than the contents of the curriculum (Milson \& Mehlig, 2002; Revell \& Arthur, 2007). By emphasising that there is nothing more effective than a good teacher in gaining values, Lee (2001) pointed out that a student formulates his/her character by imitating the teacher's behaviours, instead of following the teachings and contents of a book. In other words, students adopt more characteristics based on what they see, rather than what they hear or read (Arjoon, 2001).

According to Lee (2001), a teacher performs the following roles in character education:

- A teacher must be a role model whose teachings and behaviours are consistent. First of all, to be a good role model, one should love and respect the students as well as encourage them to have self-respect.

- A teacher should not let ethics education be limited to the school's walls. He/she should maintain a close relationship with the students' families in order to successfully transfer such knowledge into their daily lives.

- In extra-curricular and social activities, a teacher should emphasise ethical values and evaluate the impact of his/her education by observing the students' behaviours during these activities.

- A teacher should improve the students' abilities to understand their experiences and empathise with others. In order to develop his/her own empathy skills, the teacher should promote collaborative learning in class and provide the students with the competence to make democratic decisions, share their viewpoints and act fairly towards others.

- A teacher should create a positive climate in which ethical values are considered. Since such values might be secondary in a competitive classroom environment, the teacher should be able to keep the competition at a reasonable level.

In 1995, in order for the teachers to effectively perform the roles stated above, the South Korean Ministry of Education increased both the weight and time allocated for the ethics and pedagogy 
courses in undergraduate education (Kwon, 2004). In 2001, the Korean President emphasised the importance of ethics education and recommended to the Ministry of Education that ethics education should be reformed from primary school on (Joh, 2002).

\section{The effect of Confucian teachings on ethics education}

The effect of Confucius on South Koreans is visible in all parts of life (Jeong, 2005). Shin and Koh (2005) claimed that the importance given to education in this country stems from Confucian teachings. In addition, the success achieved in the economy and education in East Asia, rather than other parts of world, is not explained by academicians as a coincidence, but it is described in cultural contexts (Reid, 2000, p. 22). Unlike Western Methodists, teacher-centred Far East philosophy also stems from the impact of Confucian teachings. In sum, Confucius has had a significant impact not only in South Korea, but in all East Asian countries.

Confucius, the eminent teacher, philosopher, political theorist and founder of China's feudal system of education, is one of the country's most renowned figures. Although his real name is Qui, he is also known as either Zhongni or Kong, the latter of which is his surname (Huanyin, 1999). Confucius left his comfortable home and family at an age when most people either retire or go into seclusion, and created a cultural revival in China over the next 14 years. As a wise teacher who dedicated his life to education and mental development, Confucius was always striving to obtain knowledge (Cleary, 1992, p. 6). We can understand his lifelong passion of learning, based on the following quote: 'I surrendered myself to learning at the age of 15. I could bring my will under control at the age of 30. I got rid of doubts at the age of 40. I learned the order of heaven at 50 . I perceived everything with insight at 60 . I could realise my aspirations without harming anything at 70’ (Analects, 2:4; in Lau, 1979).

Between 532-502 B.C., Confucius assumed various positions in the government. After leaving public service, he travelled with his loyal students/followers and presented lectures throughout the country. These journeys, which lasted for approximately 13 years, helped spread his name and teachings to a significant number of people. According to Chinese historical records, he was considered to be the first liberal teacher (Smith, 2012, p. 144).

Unlike most of the philosophers of his time, Confucius focussed on concepts of management and ethics, rather than logic (Starr, 2012). In order to understand his thinking, it is necessary to first understand his basic principles, which are presented in Table 2.

Table 2: The Basic Principles of Confucian Teachings

\begin{tabular}{ll}
\hline Basic Principles & Explanation \\
\hline Chün Tzu & Virtuous person \\
Tao Te & Being moral \\
Jen & Humanity \\
Hsiao & Being a dutiful child \\
Li & Obeying rules \\
Chung Yung & Avoiding extremes \\
Cheng Ming & Behaving properly \\
Yi & Being honest and fair \\
Chih & Being wise \\
Li Chih & Being rational \\
Chung & Being loyal \\
Shu & Being merciful \\
Yung & Being courageous \\
Belief in Tien and Tien Ming & Believing in the order of the universe and fate \\
& and behaving according to Tien Tao \\
\hline Source: Adapted from Okay (2009). &
\end{tabular}


According to Confucius, being virtuous depends on loving people (Jen), being a dutiful child (Hsiao) and obeying the rules (Li). Moreover, it is necessary to completely fulfil the principles of Cheng Ming (acting properly upon your name) and Chung Yung (avoiding excessiveness) (Okay, 2009). Confucius also stated that, in order to have perfect virtue, one must have the following properties:

To be able to practise five things everywhere under heaven constitutes perfect virtue. Gravity, generosity of soul, sincerity, earnestness and kindness. If you are grave, you will not be treated with disrespect. If you are generous, you will win all. If you are sincere, people will repose trust in you. If you are earnest, you will accomplish much. If you are kind, this will enable you to employ the services of others. (Analects, 17:6; Legge, 2013, p. 320)

Confucius also described perfect virtue in the following way: 'Look not at what is contrary to propriety; listen not to what is contrary to propriety; speak not what is contrary to propriety; make no movement, which is contrary to propriety' (Analects, 12:1; Legge, 2013, p. 250). Seth (2005) claimed that, after reading and applying Confucian classics, one can become a virtuous person when he/she gains control of him/herself. In this regard, a virtuous person plays an informative role in society by serving as a role model, teacher and advisor.

Confucian teaching consists of nine basic works categorised into Five Classics (Wu-Ching) and Four Books. The former were written during Confucius's time and used in his lessons, while the latter are thought to be compiled by Meng-tsu, one of his students. Lun-Yü, which is considered to be the most important of the Four Books, means dialogues/conversations. However, it is translated as Analects, which means selection (Reid, 2000, p. 99). Although Analects was written well after his death, this work is thought to be the most reliable resource in which Confucius's leading views were compiled to form the basis of his teachings (Yuhan \& Chen, 2013).

Analects, which has garnered widespread attention from around the world, mentions the governance of state, moral principles, social order, ideal persons and ideal society. In this work, expressions, such as role model and to be honest, are widely emphasised. As Confucius stated, 'Wealth and high station are what men desire, but unless I got them in the right way, I would not remain in them. Poverty and low station are what men dislike, but even if I did not get them in the right way, I would not try to escape from them' (Analects, 4:5; Lau, 1979, p. 72). Confucius also believed that the presence of a moral person has a positive impact on those lacking sufficient morality (Reid, 2000, p. 109). He clarified this situation as follows: 'Just desire the good yourself and the common people will be good. The virtue of the gentleman is like wind; the virtue of the small man is like grass. Let the wind blow over the grass and it is sure to bend' (Analects, 12:19; Lau, 1979, p. 116).

Although Confucian teachings are thought of as a religion, it could be stated that these teachings are actually the detailed codes of interpersonal behaviours, since Confucian teachings differ from other religious teachings. More specifically, this difference is that it places one's daily life and human behaviour at the centre, rather than God and life after death (Chou, Tu \& Huang, 2013). Apart from these aspects, Confucius appraised information according to its level of feasibility in improving fairness and kindness. In addition, he stated that the goal of the information is not only about the intellectual experience (Cleary, 1992, p. 6), as shown in the following quote:

Respectfulness, without the rules of propriety, becomes laborious bustle; carefulness, without the rules of propriety, becomes timidity; boldness, without the rules of propriety, becomes insubordination; straightforwardness, without the rules of propriety, becomes rudeness. (Analects, 8:2; Legge, 2013, p. 208)

In general, Confucius accepted the inner goodness of man, but believed that it was only possible to preserve it with education. In this regard, he emphasised that education could make laws unnecessary by relying on humans, rather than the laws and judgements of the courts. According to 
him, the rules are literally unwritten, since they are based on one's heart and inner self (Reid, 2000, pp. 111-112).

Another point supporting Confucius's importance in education is that he was known as a teacher, rather than a philosopher. In Chinese, the word teacher consists of two words, meaning to teach and to make someone as respectable as a mother or father, respectively. According to the teachings of Confucius, being a teacher is an emotionally satisfying occupation as well as an accepted and respectable one (Starr, 2012). Moreover, since a teacher is considered to be as important as a father/mother or a king/queen, he/she should be respected at the same level (Aum, 2001; Kwon, 2004; Shin \& Koh, 2005). This fact is taught as early as kindergarten, since it is believed that the child is in debt to his/her father and mother, and thus, he/she should always respect the teacher's efforts (Lee, 2001, p. 16). In addition, since teaching is considered to be one of the most respectable occupations in South Korea, it is apparent that Confucian teachings are still effective to this day (Yum, 2000). Finally, by stating, 'In teaching there should be no distinction of classes' (Analects, 15:38; in Lau, 1979, p. 305), Confucius pointed out that education is not a service limited to only aristocrats, but to all people (Cleary, 1992, p. 3).

Confucius believed that the level and quality of interpersonal behaviours are important. Moreover, he believed that good behaviour can be taught and that each person should be given an equal opportunity to learn the code of conduct, which is one of the conditions of being a so-called gentleman (chun-tzu). In this regard, one must devote his/her life to reading and living according to certain moral rules in order to become a gentleman. According to Confucius, if moral rules are taught to everyone, then they can become moral citizens (Reid, 2000, pp. 106-108). This optimistic viewpoint prevents the mistake of only caring about the education of a specific class of people, which is based on the presupposition that only good actions flow from certain individuals.

\section{CONCLUSION}

The rapid changes in science and technology have highlighted the importance of ethics in education. Ethics is the evaluation of an individual's attitude and behaviours in terms of being good (bad) or right (wrong), while ethics education is the process of conveying the values to subsequent generations. More specifically, the aim of ethics education is to provide individuals with the ability to judge moral and ethical values (Aydin, 2015, p. 174); that is, those who can ask the following questions: What should I do? and Is it right to do it? Ethics is especially important in education since teachers and administrators are besieged with moral questions and they have the overwhelming responsibility of fostering students' (i.e. the next generation of citizens) education and moral goodness (Haynes, 2002, p. 17).

Confucius explained that the aim of moral education is to help each person improve his/her moral character and conduct, and become a completely virtuous person. For Confucius, virtue is not innate, but it can be learned via education (Yuhan \& Chen, 2013). If we consider this point, then one of the most important functions of educational institutions is to nurture individuals to become good citizens.

Based on Confucian teachings, there is the idea of a person being one with the universe and achieving a certain level of goodness. Hence, the teacher's goal should be to nurture students to achieve the same level of goodness (or universal goodness) as that of him/herself. However, Western societies assume that human beings are innately limited, since they are innately sinful. Conversely, in Eastern culture, human beings are open to universal knowledge of which one of the primary goals is to ensure that each person can continue to develop by gaining as much knowledge as possible through education (Starr, 2012). Thus, this perspective has a considerable effect on ethics education in South Korea. 
In South Korea, ethical values are included by integrating the basic principles of Confucian teachings into the curriculum. Moreover, the fact that ethics courses are offered from the primary school to undergraduate levels, it has ensured that ethical values are longer lasting in Korean society, compared to Western cultures. In other words, since the social structure of South Korea has a strong connexion to its national culture, the scarcity of inter-conflicting values has made it easier for ethics education to be adopted by society.

Schools are not the only locations where students receive ethics education. Families and societies are two other institutions that play a critical role in instilling ethical values. In this regard, the student's character is not only based on what he/she has learned at school, but what he/she has learned in society and family (Revell \& Arthur, 2007). Therefore, it is important that a coherent school-family relationship is established in order to increase the quality of such education.

Moreover, the passion for education by supportive families, including their pursuit of their children's education, has enabled ethics education to continue at home. Seth (2005) linked this situation with the families' willingness to make certain sacrifices such as continuing such studies on holidays and Sundays (Joh, 2002). In fact, this passion for education, known as education fever (kyoyukyeol), is one of the fundamentals of Korean society (Park, 2010). Seth (2005) also stated that this passion is connected to Confucian teachings, while Lee (2001) described it as 'the obsession with education'.

According to Confucius, a good teacher is a good role model. In this context, in order to provide students with ethical values, it is important to train all teachers in conveying these values. The continuity of these trainings in South Korea might be related to the ethics courses and character education that they received during their student years. In addition, since all of the teachers have been fostered according to Confucian teachings (from the kindergarten to university levels); they are most likely to take Confucius as a role model for themselves.

Unlike the West, South Korea has a more traditional societal culture in which its education system emphasises the importance of social values and moral development. One example of this ethical stance can be seen when individuals and institutions effectively rely on themselves during adverse events. In this regard, it is no surprise that, until the 1980s, all civil servants, private sector workers and those going abroad for educational purposes were required to take an ethics examination, as a precondition.

\section{REFERENCES}

Arjoon, S. (2001). Moral development: a case for character education, Caribbean Studies Association. 26th Annual Conference, St. Maarten.

Aum, W. Y. (2001). A study of Korean church problems in view of the biblical church model. (Unpublished $\mathrm{PhD}$ Thesis), Florida Beacon Seminary.

Aydin, İ. (2015). Eğitim ve ögretimde etike [Ethics in education and training], Ankara: Pegem Academy Publishing.

Baek, H. J. (2002). A comparative study of moral development of Korean and British children. Journal of Moral Education, 31(4), 373-391.

Bakioglu, A. \& Silay, N. (2014). Yükesek ögretim ve ögretmen yetistirmede karakter eğitimi [Character education in higher education and teacher education] ( $3^{\text {rd }}$ edt.), Ankara: Nobel Academic Publishing.

Canda, E. R. \& Canda, H. J. (1996). Korean spiritual philosophies of human service: Current state and prospects. Social Development Issues, 18(3), 53-70.

Canda, E. R., Shin, S., \& Canda, H. J. (1993). Traditional philosophies of human service in Korea and contemporary social work implications. Social Development Issues, 15(3), 84-104.

Chen, G.-M., \& Chung, J. (1997). The "Five Asian Dragons": Management behaviors and organizational communication. In L. A. Samovar \& R. E. Porter, Intercultural communication: $A$ reader (pp. 317-328). Belmont, CA: Wadsworth. 
Levent, F. \& Pehlivan, M. (2017). Confucianism's influence on ethics education in South Korea. Journal of Human Sciences, 14(1), 321-330. doi:10.14687/jhs.v14i1.4372

Choi, S.-C. \& Han, G. (2008). Shimcheong psychology: A case of an emotional state for cultural psychology. International Journal for Dialogical Science, 3(1), 205-224.

Chou, M. J., Tu, Y. C., \& Huang, K. P. (2013). Confucianism and character education: a Chinese view. Journal of Social Sciences, 9(2), 59-66.

Chu, K. F. \& Carew, R. (1990). Confucianism: Its relevance to social work with Chinese people. Australian Social Work, 43(3), 3-9.

Chung, D. (2001). Confucianism. In M. Van Hook, B. Hugen, \& M. Aguilar (Eds.). Spirituality within religious traditions in social work practice (pp. 73-97). Pacific Grove, CA: Brooks/Cole.

Cleary, T. (1992). The essential Confucius, San Francisco: Harper Collins Publishers.

Dirlik, A. (1995). Confucius in the borderlands: global capitalism and the reinvention of Confucianism, Boundary, 2(2), 229-273.

Fangchuan, H. (2010). The construction of East Asian culture and cultural awareness. Procedia Social and Bebavioral Sciences, 5(2), 7198-7202.

Fitzgerald, J. (1994). Why study Asia?, Interaction, 22(30), 12-18.

Haynes, F. (2002). The ethical school: consequences, consistency and caring. London: Taylor and Francis.

Huanyin, Y. (1999). Confucius (K'ung T₹u), UNESCO: International Bureau of Education. Retrieved from http://www.ibe.unesco.org/publications/ThinkersPdf/confucie.PDF

Jeong, C. (2005). Formulating a developmentally appropriate and culturally sensitive program of moral education-A Korean example. The Social Studies, 96(2), 79-85.

Joh, J. H. (2002). A dilemma in moral education in the Republic of Korea: the limitation of individualistic cognitive approaches. Journal of Moral Education, 31(4), 393-406.

International Qualifications Assessment Service. (2009). International education guide for the assessment of education from South Korea. Retrieved from http://work.alberta.ca/documents/koreainternational-education-guide.pdf

Kim, K. S., Chung, M. K., \& Kim, D. K. (2012). Successful strategy for training teachers in Korean education. Korean Educational Development Institute (KEDI), Ministry of Strategy and Finance, Republic of Korea.

Kim-Renaud, Y. K., Grinker, R. R., \& Larsen, K. W. (2005). "Korean education". The Sigur Center Asia Papers, 24, 33-52.

Kim, E. G. \& Han, Y. K. (2002). Attracting, developing, and retaining effective teachers: Background report for Korea. Seoul: Korean Educational Development Institute.

Kutanis, R. Ö., \& Tunç, T. (2010). Güney Kore örgüt kültürü: Konfüçyanizm’in etkileri açısından bir değerlendirme [South Korean organizational culture: an evaluation in the effects of Confucianism]. Erciyes University IIBBF Journal, 35, 55-75.

Kwon, O. N. (2004). Mathematics teacher education in Korea. In International Congress on Mathematical Education (ICME-10), Copenhagen, Denmark.

Lau, D. C. (1979). Confucius-The Analects (Lun Yu), Penguin Group: England.

Lee, I-J. (2001). The proper directions and practical ways for character education in the Korean elementary school. Asia Pacific Education Review, 2(2), 72-84.

Lee, J-K. (2001). Confucian thought affecting leadership and organizational culture of Korean higher education. Retrieved from http://radicalpedagogyicaap.org/content/issue3 3/5lee.html.

Lee, J. (2001). Education policy in the Republic of Korea: building block or stumbling block? Human Development Network, Washington DC: World Bank.

Legge, J. (2013). Confucius, Confucian Analects, the great learning, the doctrine of the mean, New York: Courier Corporation, Inc.

Leong, F. T. L., Huang, J. L., \& Mak, S. (2014). Protestant work ethic, Confucian values, and workrelated attitudes in Singapore. Journal of Career Assessment, 22, 304-316.

Levent, F. \& Gökkaya, Z. (2014). Education policies underlying South Korea's economic success, Journal Plus Education, 10(1), 275-291. 
Levent, F. \& Pehlivan, M. (2017). Confucianism's influence on ethics education in South Korea. Journal of Human Sciences, 14(1), 321-330. doi:10.14687/jhs.v14i1.4372

Lim, T-S. \& Choi, S-H. (1996). Interpersonal relationships in Korea. In W. B. Gudykunst, S. TingToomey, \& T. Nishida (Eds.), Communication in personal relationships across cultures (pp. 122136). Thousand Oaks, CA: Sage.

Lu, L., Gilmour, R., \& Kao, S. F. (2001). Cultural values and happiness: An East-West dialogue. The Journal of Society Psychology, 141(4), 477-493.

Milson, A. J., \& Mehlig, L. M. (2002). Elementary school teachers' sense of efficacy for character education. Journal of Educational Research, 96(1), 47-54.

MOE (Ministry of Education). (2014a). Overview. Retrieved from http://english.moe.go.kr/web/1693/site/contents/en/en 0203.jsp.

MOE (Ministry of Education). (2014b). Educational administration and finance. Retrieved from http://english.moe.go.kr/web/1700/site/contents/en/en 0212.jsp

MOEHRD (Ministry of Education and Human Resources Development). (2004). Quality education for all young people: challenges, trends and priorities. Retrieved from http://www.ibe.unesco.org/National Reports/ICE 2004/korearep.pdf

Moon, Y. L. (1995a). The status and problems of moral education in primary and secondary schools in Korea, The Snu Journal of Education Research, 5, 1-10.

Okay, B. (2009). Lun Yü ve Kutadgu Bilig'de devlet yönetimi [State management in Lun Yü and Kutadgu Bilig]. ICANAS, 38, 307-315.

Park, D. M. \& Müller, J. C. (2014). The challenge that Confucian filial piety poses for Korean churches, HTS Teologiese Studies/Theological Studies, 70(2), 1-8.

Park, S. (2010). Teacher policies in Korea. Retrieved from http://siteresources.worldbank.org/EDUCATION/Resources/Teacher Policies in Kore a1.pdf

Park, S. Y. (2010). Crafting and dismantling the egalitarian social contract: The changing statesociety relations in globalizing Korea. The Pacific Review, 23(5), 579-601.

Pieper A. (2003). Einführung in die ethic, Tübingen: Francke.

Plantilla, J. R. \& Raj, S. L. (1997). Human rights in Asian cultures-continuity and change, Osaka: Hurights Osaka.

Reid, T.R. (2000). Confucius lives next door: What living in the east teaches us about living in the west. New York: Vintage Books.

Revell, L. \& Arthur, J. (2007). Character education in schools and the education of teachers. Journal of Moral Education, 36(1), 79-92.

Seth, M. J. (2005). Popular demand and education in South Korea: An historical overview. In conference "Profits and challenges of education in Korea," by the Korea Argentina Study Center, University of Buenos Aires.

Shin, S., \& Koh, M. S. (2005). Korean education in cultural context. Essays in Education, 14, 1-10.

Sorensen, C. W. (1994). Success and education in South Korea. Comparative Education Review, 38(1), $10-35$.

Smith, H. (2012). The religions of man, Tokyo: Ishi Press International.

Starr, D. (2012). China and the Confucian education model. Universitas, 21, 1-27.

Yuhan, X. I. E., \& Chen, G. E. (2013). Confucius' thoughts on moral education in China. CrossCultural Communication, 9(4), 45-49.

Yum, J. O. (1994). The impact of Confucianism on interpersonal relationships and communication patterns in East Asia. In L. A. Samovar \& R. E. Porter (Eds.), Intercultural communication: A reader (7th ed., pp. 75-94). Belmont, CA: Wadsworth. 